Journal of Experimental and Clinical Medicine https://dergipark.org.tr/omujecm

Research Article

$\mathrm{J}$ Exp Clin Med

2021; 38(4): 511-515

doi: $10.52142 /$ omujecm.38.4.20

\title{
Comparison of subacromial corticosteroid injection and physical therapy in patients with subacromial impingement syndrome: A prospective, randomized trial

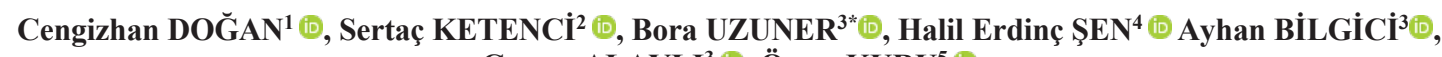 Gamze ALAYLI ${ }^{3}$ i⿺, Ömer KURU ${ }^{5}$ (i)
}

\footnotetext{
${ }^{1}$ Department of Physical Medicine and Rehabilitation Clinic, Medicana İnternational Samsun Hospital, Samsun, Turkey

${ }^{2}$ Department of Rheumatology Clinic, Ministry of Health Manisa City Hospital Hospital, Manisa, Turkey

${ }^{3}$ Department of Physical Medicine and Rehabilitation, Faculty of Medicine, Ondokuz Mayıs University, Samsun, Turkey

${ }^{4}$ Department of Physical Medicine and Rehabilitation Clinic, Çarşamba State Hospital, Samsun, Turkey

${ }^{5}$ Department of Physical Medicine and Rehabilitation, Dr. Cemil Taşçığlu City Hospital, İstanbul, Turkey
}

\begin{abstract}
\begin{tabular}{ccccc}
\hline Received: 22.03 .2021 & $\bullet$ & Accepted/Published Online: 08.04 .2021 & • & Final Version: 30.08 .2021 \\
\hline
\end{tabular}
Abstract

The aim of this randomized trial was to evaluate the efficacy of subacromial corticosteroid injection and physical therapy (PT) in patients with subacromial impingement syndrome (SIS). Forty patients who diagnosed as SIS were included in this study and were randomly assigned to the PT and injection groups. Pain during rest, sleep and motion were evaluated by visual analog scale (VAS). Disability was determined by CostantMurley score. Physical and social functions were evaluated with Short Form-36 (SF-36). Active range of motion (ROM) was measured by goniometer. Patients were evaluated at baseline, $3^{\text {rd }}$ and $8^{\text {th }}$ weeks of the therapy. PT continued for 3 weeks with ultrasound and interferential current combined to local heat and exercise. For patients in the injection group, a single steroid injection of $40 \mathrm{mg}$ triamcinolone acetonide into the subacromial space was combined with exercise. After eight weeks, significant improvements at pain, SF-36 and Costant-Murley scores were observed in both groups $(\mathrm{p}<0.001)$. Improvement rates of pain during sleep and motion were significantly higher in PT group than the injection group after 8 weeks $(p<0.01)$. Significant improvements were determined at ROM in both groups $(p<0.001)$. No statistically significant differences were found between two groups in terms of Costant-Murley and ROM scores. Results of the PT group were significantly better in terms of physical and social function, and pain subscores of SF-36 $(\mathrm{p}<0.05)$. Our results suggest that both PT and corticosteroid injection have beneficial effects on shoulder mobility and pain relief in SIS. PT should be an alternative and effective treatment method to corticosteroid injection in SIS.
\end{abstract}

Keywords: corticosteroid injection, interferential current, subacromial impingement syndrome, ultrasound

\section{Introduction}

Shoulder impingement syndrome is commonly referred to as painful arc syndrome, subacromial impingement syndrome (SIS), supraspinatus syndrome. SIS and rotator cuff tendinitis are considered to be the most common cause of shoulder pain and disability. SIS is a clinical syndrome that indicates pain and pathology related with the encroachment of the subacromial tissues as a result of the narrowing of the subacromial space (1).

The cause of SIS is considered to be multifactorial with both extrinsic and intrinsic factors involved in its pathogenesis. Extrinsic factors such as acromial shape and subacromial spurs, often associated with acromioclavicular joint arthritis, have been described. Intrinsic factors such as rotator cuff dysfunction (RCD) leading to superior head migration, and scapular dyskinesis leading to scapular malposition, also contribute and can be reversed with physical therapy. These injured tissues incite a local inflammatory response, which leads to tissue edema and pain $(1,2)$.

Many treatment modalities have been employed in attempts to relieve pain and restore function of the affected shoulder. Nonoperative treatment options for SIS include rest, ice, physical therapy (PT), electromagnetic radiation, corticosteroid injections, and systemic nonsteroidal antiinflammatory drugs (NSAIDs) (3).

There is still little knowledge about the efficacy of most conservative treatment options for SIS. The injection of corticosteroids into the subacromial space is a procedure commonly performed for impingement. However, there is no consensus about whether subacromial injection is superior to other conservative treatment options. Corticosteroids have been reported to be associated with tendon rupture, subcutaneous atrophy, and articular cartilage changes. Due to the potentially serious side effects, frequent use of corticosteroid injections is avoided (4). 
There are limited number of studies evaluated the effect of PT intervention in patients with SIS. Although ultrasound (US) is the frequently used as a PT method for soft tissue disorders, there are limited and conflicting data regarding the effectiviness of US therapy in SIS $(3,5)$. In the present study, we aimed to compare the efficacy of subacromial corticosteroid injection and ultrasound in the treatment of SIS.

\section{Materials and methods}

The study was planned as a prospective, randomized, clinical trial with an 8-week follow-up period. It consisted of 40 consecutive patients, who were suffering from shoulder pain and diagnosed as SIS, with physical examination and Magnetic Resonance Imaging (MRI) at Ondokuz May1s University, Medical Faculty, Department of Physical Medicine and Rehabilitation Clinic. Exclusion criteria were as follows; instability of shoulder, infection, decompensated heart failure, cardiac pace-maker, status angina, asthma, seizure, neurological deficiency, shoulder and neck surgery, history of PT and corticosteroid injection at last six months, pregnancy, positive drop arm test, rupture of $\mathrm{RC}$, adhesive capsulitis (AC), rheumatologic disases, cervical radiculopathy, hemorrhagic diathesis and diabetes mellitus. The study was approved by the local ethics committee and all patients gave their written informed consent.

All participants were questioned about demographic and clinical characteristics. In physical examination Neer, Hawkins, Painful arc, Drop arm, Supraspinatus tests were evaluated. Active ROM degrees were measured by a goniometer, at supine position by the same physician blinded to the treatment of patients. Rotations were measured while shoulder was at $90^{\circ}$ abduction. Degrees of abduction, flexion, internal rotation, and external rotation were recorded.

Pain at rest, motion and sleep periods were evaluated with $10 \mathrm{~cm}(0=$ no pain, $10=$ severe pain $)$ visual analog scale (VAS).

Shoulder functions were evaluated with Constant-Murley Shoulder Score. It is an easy, cheap, and reliable scale which has been used for the results of surgery, conservative treatment and traumatic shoulders since 1980s. There are 100 points including 15 points for pain, 20 points for daily activities, 40 points for active ROM and 25 points for strength (6).

Daily living activities were evaluated with Short Form-36 (SF-36), which was found reliable and valid in Turkish population (7). Forty patients were randomly assigned into two groups. In PT group ( $\mathrm{n}=20)$, hot pack for 20 minutes, US for seven minutes $\left(1.5 \mathrm{Watt} / \mathrm{cm}^{2}\right.$, constant mode, $\left.1 \mathrm{MHz}\right)$ and interferential current (IC) for 20 minutes $(100 \mathrm{~Hz})$ were applied to the patients, five times per week for three weeks.

In injection group, subacromial injection was performed by the same physician with $40 \mathrm{mg} / 1 \mathrm{ml}$ triamcinolone acetonide. For every patient, a single injection was applied with lateral approach, by 5cc-21-gauge injector, in sterile conditions, to the subacromial space after marking the lateral side of acromion.

Passive ROM, stretching and pendulum exercises were started in both groups. After gaining full ROM, isometricisotonic strenghtening exercises for RC and scapula stabilizer muscles were started with dumbbell and therabands. In PT group, exercises were applied in hospital twice per day with 10 repetitions while they were performed at home with the same conditions in injection group. All patients were allowed to use $275 \mathrm{mg}$ Naproxen Sodium, twice per day at the first three weeks of the therapy. All subjects were evaluated by the same physician at the baseline, at the end of $3^{\text {th }}$ week and $8^{\text {th }}$ week.

\subsection{Statistical analysis}

Statistical analyses were performed using SPSS software, version 15.0. For continuous variables Mean \pm Standard Deviation (Mean \pm SD), and for frequencies percents (\%) were reported. All variables were analyzed for normally distribution by Shapiro Wilk test. In group comparisons Paired t-test and Wilcoxon test were used. Mann Whitney u test and t-test were used for intergroup comparisons. In group comparisons, Mc Nemar Chi square test was used for the countable variables, and in intergroup comparisons Chi square test was used. $\mathrm{P}<0.05$ was accepted significant for all statistical measurements.

\section{Results}

Forty patients-23 female (57.5\%) and 17 male (42.5\%)-were included in the study. Ages ranged from 29 to 63 . There were no differences between groups in terms of age, gender and duration of the pain $(p>0.05)$. The demographic characteristics of the patients are shown in Table 1.

Table 1. Demographic characteristics

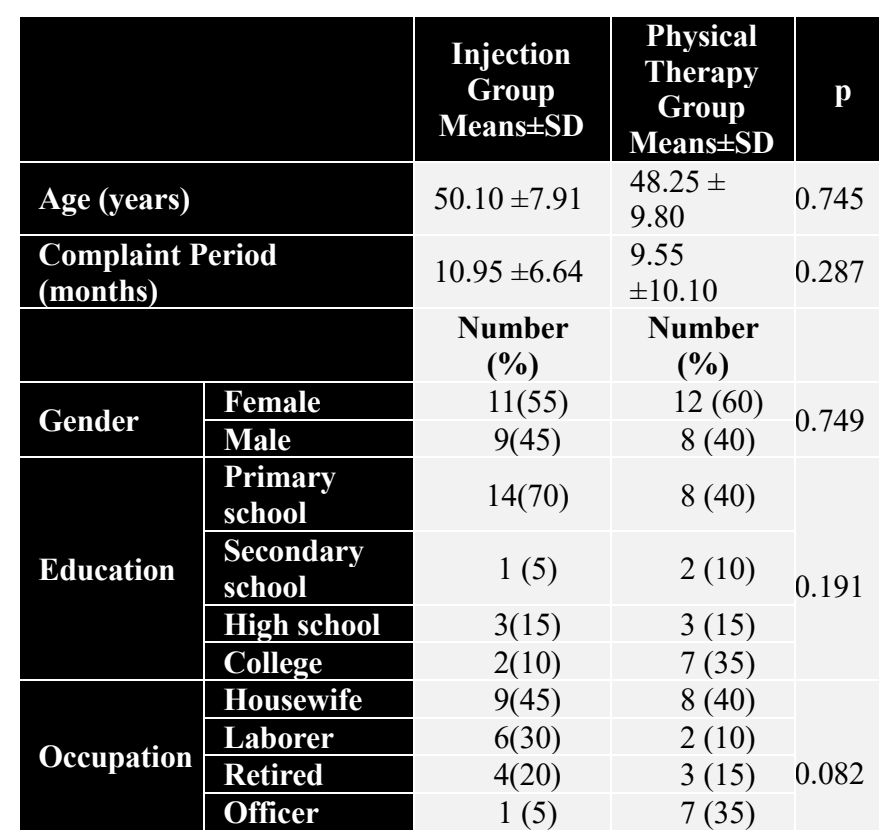


Right side affected patients were $13(65 \%)$ in injection group and $12(60 \%)$ in PT group. Dominant hand of most patients was right; $17(85 \%)$ in injection group and $18(90 \%)$ in PT group, respectively. There were no differences between the groups for dominant hands and affected sides $(\mathrm{p}>0.05)$.

In injection group, Neer test which was positive in $90 \%$ of the patients at the baseline decreased to $35 \%$ and $15 \%$ at the end of $3^{\text {rd }}$ week and $8^{\text {th }}$ week. In PT group Neer test which was positive in all patients at the baseline decreased to $35 \%$ and $5 \%$ at the end of $3^{\text {rd }}$ week and $8^{\text {th }}$ week. Hawkins tests were positive in all patients in both groups at the baseline. In injection group they decreased to $65 \%$ and $40 \%$ at the end of 3 rd week and 8 th week. In PT group, these rates were $60 \%$ and $15 \%$ respectively.

The mean ROM measurements improved significantly in both groups at the $3^{\text {rd }}$ and $8^{\text {th }}$ weeks $(p<0.001$ for each). All measurements were better in PT group than injection group, but there were no significant differences between groups for active ROM at the end of $3^{\text {rd }}$ week and $8^{\text {th }}$ week $(p>0.05)$ (Table 2).

Table 2. Comparison of range of motion

\begin{tabular}{|c|c|c|c|c|}
\hline & $\begin{array}{l}\text { Injection } \\
\text { Group }\end{array}$ & $\begin{array}{c}\text { Physical } \\
\text { Therapy } \\
\text { Group }\end{array}$ & \multirow[t]{2}{*}{$\mathbf{p}$} \\
\hline & & Means \pm SD & Means \pm SD & \\
\hline \multirow{3}{*}{ Flexion } & Baseline & $126.5 \pm 39.1$ & $126.5 \pm 35.13$ & 0.978 \\
\hline & $3^{\text {th }}$ week & $146.5 \pm 31.83$ & $163.0 \pm 19.76$ & 0.108 \\
\hline & $8^{\text {th }}$ week & $159.0 \pm 28.26$ & $171.5 \pm 20.84$ & 0.091 \\
\hline \multirow{3}{*}{ Abduction } & Baseline & $122.75 \pm 42.41$ & $120.0 \pm 37.55$ & 0.838 \\
\hline & $3^{\text {th }}$ week & $149.50 \pm 27.99$ & $163.75 \pm 14.9$ & 0.145 \\
\hline & $8^{\text {th }}$ week & $160.50 \pm 24.59$ & $170.5 \pm 20.89$ & 0.123 \\
\hline \multirow{3}{*}{$\begin{array}{l}\text { Internal } \\
\text { Rotation }\end{array}$} & Baseline & $55.25 \pm 13.71$ & $51.75 \pm 12.69$ & 0.397 \\
\hline & $3^{\text {th }}$ week & $64.00 \pm 12.31$ & $67.75 \pm 8.02$ & 0.333 \\
\hline & $8^{\text {th }}$ week & $70.25 \pm 9.79$ & $75.50 \pm 8.87$ & 0.303 \\
\hline \multirow{3}{*}{$\begin{array}{l}\text { External } \\
\text { Rotation }\end{array}$} & Baseline & $64.50 \pm 15.03$ & $61.00 \pm 17.13$ & 0.527 \\
\hline & $3^{\text {th }}$ week & $75.75 \pm 13.50$ & $80.75 \pm 9.21$ & 0.285 \\
\hline & $8^{\text {th }}$ week & $80.25 \pm 13.42$ & $86.00 \pm 0.94$ & 0.060 \\
\hline
\end{tabular}

$\mathrm{p}<0.05$; significant, SD; standard deviation

At $3^{\text {rd }}$ week, both treatment methods appeared to have similar efficacy on pain and disability. Both treatment options were similarly effective in improving the mean VAS activity pain and Constant-Murley scores. At the end of an 8-week follow-up period, the activity pain and Constant-Murley scores were significantly improved in both of the groups without significant difference between two treatment methods. There was a significant difference between the two groups with regard to the night pain and activity pain sores at $8^{\text {th }}$ week. After 8 weeks, VAS pain scores at motion and at sleep were significantly better in PT group than the injection group (Table 3).

When we compared both groups for SF-36, physical function, social function, emotional role function and pain subscores in PT group were significantly better than the injection group at the end of $8^{\text {th }}$ week $(p<0.05$ each other) (Table 4.) There were no differences for general health, change in health, mental health and fitness/fatigue scores in SF-36 ( $p>0.05)$. In both groups all SF-36 scores except for emotional role function in injection group improved significantly at the end of $3^{\text {rd }}$ week and $8^{\text {th }}$ week $(p<0.05)$.

Table 3. Comparison of VAS pain and Constant-Murley scores

\begin{tabular}{|c|c|c|c|c|}
\hline & $\begin{array}{l}\text { Injection } \\
\text { Group }\end{array}$ & $\begin{array}{l}\text { Physical } \\
\text { Therapy } \\
\text { Group }\end{array}$ & \multirow[t]{2}{*}{ p } \\
\hline & & Means \pm SD & $\begin{array}{c}\text { Means } \pm \\
\text { SD }\end{array}$ & \\
\hline \multirow{3}{*}{ VAS rest } & Baseline & $4.55 \pm 1.50$ & $5.10 \pm 2.42$ & 0.394 \\
\hline & $3^{\text {th }}$ week & $1.35 \pm 1.53$ & $0.95 \pm 1.05$ & 0.341 \\
\hline & $8 t^{\mathrm{h}}$ week & $1.40 \pm 1.53$ & $0.85 \pm 1.26$ & 0.224 \\
\hline \multirow{3}{*}{$\begin{array}{l}\text { VAS } \\
\text { motion }\end{array}$} & Baseline & $8.20 \pm 1.73$ & $8.30 \pm 1.75$ & 0.814 \\
\hline & $3^{\text {th }}$ week & $4.15 \pm 1.84$ & $3.50 \pm 1.31$ & 0.378 \\
\hline & $8^{\text {th }}$ week & $3.70 \pm 1.89$ & $2.00 \pm 1.65$ & 0.006 * \\
\hline \multirow{3}{*}{$\begin{array}{l}\text { VAS } \\
\text { sleep }\end{array}$} & Baseline & $5.90 \pm 2.84$ & $6.25 \pm 3.16$ & 0.663 \\
\hline & $3^{\text {th }}$ week & $2.10 \pm 1.94$ & $1.45 \pm 1.73$ & 0.260 \\
\hline & $8^{\text {th }}$ week & $2.00 \pm 2.10$ & $0.55 \pm 1.14$ & 0.006 * \\
\hline \multirow{3}{*}{$\begin{array}{l}\text { Constant } \\
\text {-Murley }\end{array}$} & Baseline & $41.10 \pm 13.4$ & $39.50 \pm 11.9$ & 0.626 \\
\hline & $3^{\text {th }}$ week & $57.70 \pm 10.3$ & $62.20 \pm 7.47$ & 0.616 \\
\hline & $8^{\text {th }}$ week & $62.95 \pm 10.9$ & $66.40 \pm 9.47$ & 0.186 \\
\hline
\end{tabular}
$\mathrm{p}<0.05$; significant, SD; standard deviation, VAS; Visual anolog scale

Table 4: Comparison of Short Form-36 subscores

\begin{tabular}{|c|c|c|c|c|}
\hline & & $\begin{array}{c}\text { Injection } \\
\text { Group } \\
\text { Means } \pm \text { SD }\end{array}$ & $\begin{array}{c}\text { Physical } \\
\text { Therapy } \\
\text { Group } \\
\text { Means } \pm \text { SD }\end{array}$ & $\begin{array}{c}\mathbf{P} \\
\text { Value }\end{array}$ \\
\hline \multirow{3}{*}{$\begin{array}{l}\text { Physical } \\
\text { function }\end{array}$} & Baseline & $48,80 \pm 16,64$ & $59,00 \pm 22,74$ & 0,106 \\
\hline & $\begin{array}{l}\text { 3th } \\
\text { week }\end{array}$ & $66,50 \pm 16,06$ & $75,75 \pm 15,83$ & 0,085 \\
\hline & $\begin{array}{l}\text { 8th } \\
\text { week }\end{array}$ & $69,50 \pm 16,21$ & $81,75 \pm 17,18$ & $0,011^{*}$ \\
\hline \multirow{3}{*}{$\begin{array}{l}\text { Social } \\
\text { function }\end{array}$} & Baseline & $41,00 \pm 17,98$ & $48,40 \pm 21,23$ & 0,394 \\
\hline & 3th week & $59,95 \pm 16,53$ & $69,85 \pm 13,94$ & 0,067 \\
\hline & 8th week & $65,40 \pm 21,87$ & $78,70 \pm 15,32$ & $0,019^{*}$ \\
\hline \multirow{3}{*}{$\begin{array}{l}\text { Physical } \\
\text { role } \\
\text { function }\end{array}$} & Baseline & $23,75 \pm 18,97$ & $28,75 \pm 30,64$ & 0,897 \\
\hline & 3th week & $47,50 \pm 31,30$ & $69,15 \pm 26,11$ & $0,025^{*}$ \\
\hline & 8th week & $65,00 \pm 32,84$ & $81,25 \pm 29,10$ & 0,066 \\
\hline \multirow{3}{*}{$\begin{array}{l}\text { Emotional } \\
\text { role } \\
\text { function }\end{array}$} & Baseline & $54.65 \pm 31,10$ & $49,65 \pm 33,23$ & 0,681 \\
\hline & 3th week & $68,10 \pm 33,40$ & $74,75 \pm 30,48$ & 0,532 \\
\hline & 8th week & $69,75 \pm 32,38$ & $88,20 \pm 24,96$ & $0,039^{*}$ \\
\hline \multirow{3}{*}{ Pain } & Baseline & $34,65 \pm 16,46$ & $35,75 \pm 20,77$ & 0,989 \\
\hline & $\begin{array}{c}\text { 3th } \\
\text { week }\end{array}$ & $63,25 \pm 15,91$ & $72,65 \pm 14,10$ & 0,117 \\
\hline & 8th week & $68,80 \pm 21,15$ & $81,65 \pm 15,61$ & $0,040^{*}$ \\
\hline
\end{tabular}

$\mathrm{P}<0,05$ Significant SD: Standard Deviation

\section{Discussion}

The aims of the conservative treatment in SIS are to improve the shoulder functions, to provide full ROM and to obtain a painless shoulder by reducing the inflammatory response (8). There is not a standard conservative treatment for SIS. Corticosteroid injection is a very common treatment method for SIS. However, there is not a consensus on its effects and initial treatment is controversial for some authors (9). 
Therefore, alternative methods are needed. Local and deep heat therapies and analgesic currents are the most commonly used physical therapy methods for SIS. In our study we compared the effectiveness of corticosteroid injection with the effectiveness of PT, including local heat, US and IC.

US is one of the most common investigated PT methods which may have the potential to induce biophysical effects within the soft tissue. It is assumed to have thermal effects on the target tissue resulting in an increase in blood flow, cell metabolism and tissue regeneration, and also reducing inflammation, edema and pain (10). There are several studies which have reported US as an effective or ineffective therapy at soft tissue pathologies of shoulder (11-12). Ainsworth et al have compared the effectiveness of US and sham US on 221 patients with shoulder pain. After 6 weeks, they have found no differences between the groups for VAS pain (12). But in their study, diagnoses of the patients have not been indicated and the US was applied to all patients with constant dose and same period. In another study, Yildırım et al have compared four minutes or eight minutes US therapy for SIS treatment. They found that all four- or eight-minutes US therapy have benefical effects in treatment of SIS but eight minutes of ultrasound treatment was shown to be more effective than four minutes of ultrasound treatment (13).

Bicer et al. have compared the PT including US, Infrared and TENS with corticosteroid injection in shoulder pain. They have applied unique subacromial injection with methylprednisolone. At the end of the study, they have found no significant differences between the groups at VAS pain. But, in their study, there were patients diagnosed as tendinitis, bursitis and adhesive capsulitis as well as SIS (14). In our study we found that US threapy is effective as corticosteroid injection. We recruited only the patients who were diagnosed SIS. There was not any frozen shoulder as Ainsworth and colleagues's study that possibly US therapy is not effective on in. In addition, we applied US seven minutes longer like Yıldırım et al. but Ainsworth applied average four minutes per patient (13).

Our results indicate that US is effective on reduction of pain and improvement of function which are the main problem for a patient diagnosed SIS. Ultrasound therapy may have the potential to induce biophysical effects within the soft tissue. Ultrasound is assumed to have thermal effects on the target tissue resulting in an increase in blood flow, cell metabolism and tissue regeneration, and also reducing inflammation, edema and pain.

Corticosteroid injection is a very common and effective therapy on SIS. Tan et al. have compared conventional PT and corticosteroid injection as in our study. They have applied US, IC, hot-pack, exercise to PT group and corticosteroid injection with exercise to another group. As distinct from our study, they have found that VAS pain during motion and rest at first week and VAS pain during motion at $3^{\text {rd }}$ week in injection group were significantly less than the PT group. However, they have not found differences between the groups for the pain scores at the $6^{\text {th }}$ week (15). The early and significant improvement at pain can be explained with the anesthetic added to the corticosteroid injection treatment. Because, combination of corticosteroid and local anesthetics reduces the pain. Additionaly, in their study, Constant-Murley scores were significantly better in injection group at the end of the first week but, there were no differences between the groups at the end of 6 th week.

Levendoglu et al have compared corticosteroid injection treatment at SIS, with 15 sessions-PT program including US, TENS and hot-pack. Similar to our study, they have found significant improvements at all parameters in both groups at the end of the study. Contrary to our study, they have observed better significant improvements in injection group at VAS pain during rest and active motion at 15 th day, first month and 3rd month of the study (16). We can explain these differences with the local anesthetic added to the injection treatment and receiving physical therapy without hospitalization of the patients in the PT group. In our study VAS pain during active motion and sleep was better in PT group than the injection group at the end of $3^{\text {rd }}$ week and $8^{\text {th }}$ week, and we believe that it was due to hospitalization and being avoided from inappropriate activities and the emotional stress of the daily living as well as the exercise therapies with physiotherapists. In several studies it has been showed that corticosteroid injection is effective on reducing inflammatory response $(16,17)$ However, some side effects after injection including pain, tendon tears, blushing and infection have been reported (18). In our study there were no side effects and we found significant improvements at VAS pain, ROM and Constant-Murley scores at the end of $3^{\text {rd }}$ and $8^{\text {th }}$ weeks, when compared with the baseline.

There are limited studies in literature which compare the effectiveness of analgesic currents. In PT modalities, analgesic currents like IC and Transcutanose Electrical Nevre Stimulation (TENS) are important for pain relief. IC is often used for acute and chronic pain of superficial and deep tissues (19). As well as the analgesic effect, it is used for antiinflammatory effect at joint sprains, for osteogenic effect at delayed fracture improvements and for sympathicolytic effect at Complex Regional Pain Syndrome $(20,21)$. Although the effect mechanism of IC is not clear, there are various suggested hypotheses, one of which is Melzack-Wall theory; increasing release of endogenic opiates, local vasodilatation and sympathetic blockade (22). There are studies which have showed that IC was as effective as TENS at the treatment of superficial and deep tissues pain. Ay et al. compared TENS with IC in patients with shoulder pain. In both groups US, hot-pack and exercise therapies were added to the treatment. At the end of the study, they observed significant improvement at pain scores and ROM in both groups, but they found no significant differences between two groups 
(23). Facci LM et al also compared effects of TENS and IC in their study and found any statistical difference between two methods for reducing VAS score (24). Another supporting result was found in the study of Ucurum SG et al. They applied TENS or IC for their patients all of whom were diagnosed as SIS similar to our study. There was similar result in terms of pain and SF 36 physical component scores at fourth week and third month assesments (25). In our study, the main complaint was pain. Therefore, we combined US and local heat therapy with IC in PT group. We found that IC might have a beneficial effect on pain relief and improvement at daily living activities in PT group. Our results suggest that US combined with local heat, and IC, and exercise program has benefit effect similar local injection treatment on shoulder mobility, pain and disability in SIS.

Our study has some limitations, one of which is that subject number was fewer and follow up period was short. That's why, studies with large numbers of subjects and long follow up periods are needed to confirm these results.

Our results showed that both PT and subacromial corticosteroid injection treatments for SIS have similar effects on pain relief, providing ROM, shoulder functions and daily living activities. PT demonstrated comparable efficacy versus local injection treatment with similar clinical response. However, PT is more effective in long-term pain relief.

\section{Conflict of interest}

There is no conflict of interest to declare.

\section{Acknowledgments}

None to declare.

\section{References}

1. Neer CS. Impingement lesions. Clin Orthop 1984; 173:70-77.

2. Garving C, Jakob S, Bauer I, Nadjar R, Brunner U. H. Impingement Syndrome of the Shoulder. Dtsch Arztebl Int. 2017;114(45):765-76.

3. Dong W, Goost H, Lin XB, Burger C, Paul C, Wang ZL, et al. Treatments for shoulder impingement syndrome: a PRISMA systematic review and network meta-analysis [published correction appears in Medicine (Baltimore). 2016;95(23):96.

4. Clark SC, Jones MW, Choudhury RR, Smith E. Bilateral patellar tendon rupture secondary to repeated local steroid injections. J Accid Emerg Med. 1995;12(4):300-1.

5. Imran M, Arshad N, Ibrahim S, Ahmed A, Minhas MT. Effects of Therapeutic Funding Ultrasound and Manual Physiotherapy in Shoulder Impingement Syndrome in Volleyball Players. JIMDC. 2017; 6(3):179-83.

6. Constant CR, Murley AHG. A clinical method of functional assesment of the shoulder. Clin Orthop 1987; 215:160-64.

7. Koçyiğit H, Aydemir O, Fişek G. Turkish validty and reliability of Short Form 36. Drug and Treatment. 1999:12;102-6.

8. Kul A, Ugur M. Comparison of the Efficacy of Conventional Physical Therapy Modalities and Kinesio Taping Treatments in Shoulder Impingement Syndrome. Eurasian J Med. 2019;51(2):139-44.
9. Koester MC, George MS, Kuhn JE. Shoulder Impingement Syndrome The American Journal of Medicine 2005; 118: 452-5.

10. Miller DL, Smith NB, Bailey MR, Czarnota GJ, Hynynen K, Makin IR, et al. Overview of therapeutic ultrasound applications and safety considerations. J Ultrasound Med. 2012;31(4):623-34.

11. Kurtaiş Gürsel Y, Ulus Y, Bilgiç A, Dinçer G, van der Heijden GJ. Adding Ultrasound in the Management of Soft Tissue Disorders of the Shoulder: A Randomized Placebo-Controlled Trial. Physical Therapy 2004;84 (4):336-43.

12. Ainsworth R, Dziedzic K, Hiller L, Daniels J, Bruton A, Broadfield J. A prospective double blind placebo-controlled randomized trial of ultrasound in the physiotherapy treatment of shoulder pain. Rheumatology 2007; 46 (5): 815-20.

13. Yildirim MA, Ones K, Celik EC. Comparision of Ultrasound Therapy of Various Durations in The Treatment of Subacromial Impingement Syndrome. J Phys Ther Sci 2013;25(9):1151-4.

14. Bicer A, Özışık S, Akşit SC, Erdoğan C. Ağrılı Omuz Tedavisinde Lokal Kortikosteroid Enjeksiyonu ve Konvansiyonel Fizik Tedavi Etkinliğinin Karşılaştırılması. Turkiye Klinikleri J Med Sci. 2005;25(4):506-12.

15. Tan K, Özgül A, Kalyon T, Göktepe S, Alaca R. Omuz Sıkışma Sendromunda Konvansiyonel Fizik Tedavi ile Steroid Enjeksiyonunun Karşılaştırılması. Türk Fiz Tıp ve Rehab Derg 2002; 48:27-32.

16. Levendoğlu F, Yılmaz H, Uğurlu H. Comparıson The Effectiveness of Physical Therapy and Corticosteroid Injection for subacromial Impingement syndrome. Arch Rheumatol 2005; 20:1-7.

17. Blair B, Rokito AS, Cuomo F, Jarolem K, Zuckerman JD. Efficacy of Injections of Corticosteroids for Subacromial Impingement Syndrome. J Bone Joint Surg 1996; 78:1885-689.

18. Sperber K. Joint and Soft Tissue Injection. In: Tan JC, Ed. Practical Manual of Physical Medicine and Rehabilitation 2006; 413-27.

19. Goats GC. Interferential Current Therapy. Br J Sp Med. 1990; 24(2):87-92.

20. Ganne JM. Stimulation of Bone Healing with Interferantial Therapy. Aust J Physiother 1988;34(1):9-20.

21. Dimitrijevic IM, Lazovic MP, Kocic MN, Dimitrijevic RM, Mancic DD, Stankovic AM. Effects of Low - Level Laser Therapy and Interferantial Current Terapy In the Treatment of Complex Regional Pain Syndrome. Turk J Phys Med Rehab 2014; 60:98-105.

22. Fredorczyk J. The Role of Physical Agents in Modulating Pain. J Hand Ther 1997; 10:110-21.

23. Ay S, Doğan SK. Comparison of Efficacy of Different Analgesic Currents in Patients with Shoulder Pain. S.D.Ü. Tıp Fak. Derg. 2009;16(3):1-5.

24. Facci LM, Nowotny Jp, Tormem F, Trevisani VF. Effects of Transcutaneous Electrical Nerve Stimulation (TENS) and Interferential Currents (IFC) in Patients with Nonspecific Chronic Low Back Pain: Randomized Clinical Trial. Sao Paulo Med J.2011;129(4): 206-16.

25. Gunay Ucurum S, Kaya DO, Kayali Y, Askin A, Tekindal MA. Comparison of Different Electrotherapy Methods and Exercise Therapy in Shoulder Impingement Syndrome: A Prospective Randomised Controlled Trial. Acta Orthop Traumatol Turc. 2018; 52:249-55. 